\title{
METABOLIC ACTIVATION OF 2,6-DIMETHYLANILINE: MUTATIONAL SPECIFICITY IN THE GPT GENE OF AS52 CELLS
}

\author{
SEO HYUN MOON ${ }^{1}$, MIN YOUNG KIM ${ }^{2 *}$ \\ ${ }^{1}$ Department of Forensic DNA, National Forensic Service, Wonju, Gangwon-do, Republic of Korea. ${ }^{2}$ Toxicology Laboratory, Faculty of \\ Biotechnology (Biomaterials), College of Applied Life Science, SARI, Jeju National University, Jeju, Republic of Korea. \\ Email: jeffmkim@jejunu.ac.kr
}

Received: 08 June 2018, Revised and Accepted: 06 July 2018

ABSTRACT

Objective: The purpose of the current work was to characterize the mechanisms of cytotoxicity and mutagenesis of a potential human bladder carcinogen 2,6-dimethylaniline (2,6-DMA).

Methods: Chinese hamster ovary (CHO) AS52 cells were exposed to either human S9 activated 2,6-DMA for 6 h or its $N$-hydroxylamine and aminophenol metabolites for $1 \mathrm{~h}$ in serum-free medium. Cell survival was determined by trypan blue exclusion $24 \mathrm{~h}$ after treatment, and 6 -thioguanine-resistant mutants at the xanthine-guanine phosphoribosyl transferase (gpt) gene locus were assessed with doses, of which relative survival is $30 \%$ or more. Nested polymerase chain reaction-based deletion analysis was also performed.

Results: AS52 cells exhibited a dose-dependent increase in cytotoxicity and mutant fraction on treatment of 2,6-DMA and its metabolites but show a considerable variation in potency with aminophenol metabolites having the highest potency and parent compound at least; at the highest 2,6-dimethylaminophenol dose $(10 \mu \mathrm{M})$, the mutant fraction in AS52 cells was 8 -fold $\left(13.2 \times 10^{-5}\right)$ greater than the spontaneous fraction of $1.62 \times 10^{-5}$. Total deletion of the gpt gene sequences was found in 1 (4\%) spontaneous and 2 (6\%) the 6-thioguanine mutants generated by $N$-hydroxy-2,6-DMA.

Conclusions: These findings indicate the mutagenicity of 2,6-DMA at the gpt gene, which is mediated through hydroxylamine and aminophenol metabolites, and contribute to the elucidation of mechanisms through which 2,6-DMA may exert its effects in vivo.

Keywords: 2,6-Dimethylaniline, Metabolic activation, Genotoxicity, AS52/guanine phosphoribosyl transferase assay.

(C) 2018 The Authors. Published by Innovare Academic Sciences Pvt Ltd. This is an open access article under the CC BY license (http://creativecommons. org/licenses/by/4. 0/) DOI: http://dx.doi.org/10.22159/ajpcr.2018.v11i9.27819

\section{INTRODUCTION}

2,6-Dimethylaniline (2,6-DMA), a well-known alkylanilines, is used as a chemical intermediate in the manufacture of pesticides, dyestuffs, antioxidants, pharmaceuticals, synthetic resins, fragrances, and other products $[1,2]$. Exposure to alkylaniline not only has been well documented in cigarette smokers [3] but also may occur from nonsmoking-related sources [4]. Smoking is associated with increased rates of bladder cancer [5]. Alkylanilines are believed to be the constituents of tobacco smoke that leads to the development of bladder cancer $[6,7]$. Several members of alkylanilines including 4-aminobiphenyl, 2-naphthylamine, and benzidine, which are extensive, have been classified and regulated as human bladder carcinogens [8]. Other alkylaniline, including 2,6-DMA, have been implicated as possible human bladder carcinogens [6,9-12].

Genotoxicity of alkylanilines has received very limited investigation to date, and the fragmented available database supports only limited conclusions. Alkylaniline is metabolized to reactive alkylhydroxylamine which can undergo further bioactivation and conjugation reactions [13-15]. These reactions include those catalyzed by cytochrome P450-dependent monooxygenases and other enzymes; the free reactive hydroxylamine may be regenerated from the conjugated form in an acidic environment [13-15]. Possible metabolic pathways leading to the formation of genotoxic DMA damage products of 2,6-DMA are shown in Fig. 1. Recent results described here indicate that alkylaniline scan be potent genotoxins for cultured mammalian cells when activated by exogenous or endogenous Phases I and II xenobiotic-metabolizing enzymes $[6,7,10-12,15]$. However, there is little information available about mutagenicity of 2,6-DMA and a detailed metabolic profile of 2,6DMA. Moreover, it is not clear whether 2,6-DMA can induce the deletions and other gross structural changes in other types of cells. Therefore, there is of considerable interest to examine the toxic effects of 2,6-DMA in the reportedly more sensitive in vitro system for mutation assay.

For this reason, we have introduced a Chinese hamster ovary (CHO) AS52 cell line that carries a single copy of Escherichia coli xanthineguanine phosphoribosyl transferase (gpt) gene functionally expressed using SV40 early promoter and stably integrated into the AS52 cell genome [16]. AS52 cells were constructed by transfecting the plasmid vector pSV gpt into a normal X-linked mammalian HPRT-deficient CHO cells. The AS52 cell line has been demonstrated to be useful with regard to the detection of both deletion and point mutations at gpt, and the low spontaneous mutation fraction (MF) and the distinct advantage of carrying a small easily manipulated mutational target make the AS52 cell line particularly suited to quantitative and molecular mutagenesis studies. The gpt structural gene is 456 base pairs (bp) with no introns versus a structural gene size of $654 \mathrm{bp}$ for HPRT, which with introns comprises a genomic HPRT locus of approximately $35 \mathrm{~kb}$ [17]. Thus, AS52 cells are sensitive to induced mutagenesis by a variety of clastogens and radiomimetic agents that are often classified as nonmutagens in other assays [17]. The purpose of the present study was to characterize the mutational profile and mechanism induced by 2,6-DMA in the gpt gene of AS52cells. We have tested the hypothesis that toxic effects of 2,6-DMA are mediated through its hydroxylamine and/or aminophenol metabolite.

\section{METHODS}

Chemicals and reagents

All cell culture reagents were purchased from Lonza (Walkersville, MD). 2,6-DMA, 6-thioguanine (6-TG), dimethyl sulfoxide (DMSO), ethyl 
methanesulfonate (EMS), and DL-isocitric acid were purchased from Sigma Chemical Co., St Louis, MO. 3,5-DMA and NADP were obtained from Acros Organics (Geel, Belgium) and Boehringer Mannheim (Indianapolis, IN), respectively.

\section{Cell cultures}

CHO AS52 cells, kindly provided by Dr. Gerald N. Wogan (Massachusetts Institute of Technology, Cambridge, MA, USA), were cultured in Ham's F-12 medium supplemented with 100 units $/ \mathrm{mL}$ penicillin, $100 \mu \mathrm{g} / \mathrm{mL}$ streptomycin, and $10 \%$ heat-inactivated fetal bovine serum (Atlanta Biologicals, Lawrenceville, GA) in a humidified atmosphere with $5 \% \mathrm{CO}_{2}$ at $37^{\circ} \mathrm{C}$. Cells were cleansed of preexisting gpt mutants by culturing in MPA medium ( $10 \mu \mathrm{g} / \mathrm{mL}$ MPA, $250 \mu \mathrm{g} / \mathrm{mL}$ xanthine, $22 \mu \mathrm{g} / \mathrm{mL}$ adenine, $11 \mu \mathrm{g} / \mathrm{mL}$ thymidine, and $1.2 \mu \mathrm{g} / \mathrm{mL}$ aminopterin) for 7 days and transferred for 3 days to medium enriched with xanthine $(11.5 \mu \mathrm{g} / \mathrm{mL})$, adenine $(3 \mu \mathrm{g} / \mathrm{mL})$, and thymidine $(1.2 \mu \mathrm{g} / \mathrm{mL})$ for recovery.

\section{2,6-DMA treatment}

Cells were placed in 6 -well plates at a density of $0.5 \times 10^{6}$ cells per well the day before treatment. Cultures were, just before treatment, washed with phosphate-buffered saline (PBS) and refed with serumfree medium containing human liver S9 mix (Moltox Inc., Boone, NC). Approximately $440 \mu \mathrm{g}$ S9 protein (16 $\mu \mathrm{L}$ fraction) and $65 \mu \mathrm{L}$ sterilefiltered core mixture contained $25 \mathrm{mg} / \mathrm{mL}$ NADP and $45 \mathrm{mg} / \mathrm{mL}$ DL-

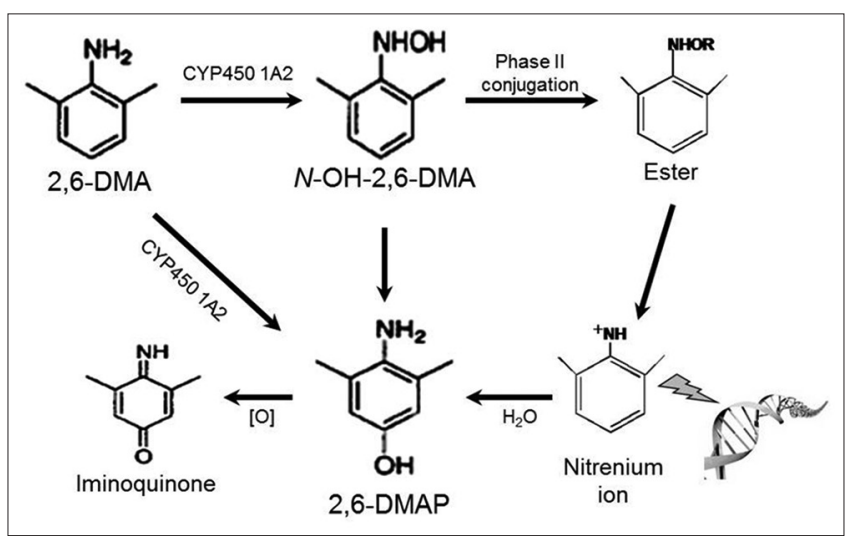

Fig. 1: Schematic representation of the presumed metabolic pathway for 2,6-dimethylaniline, Information was taken from Gan et al

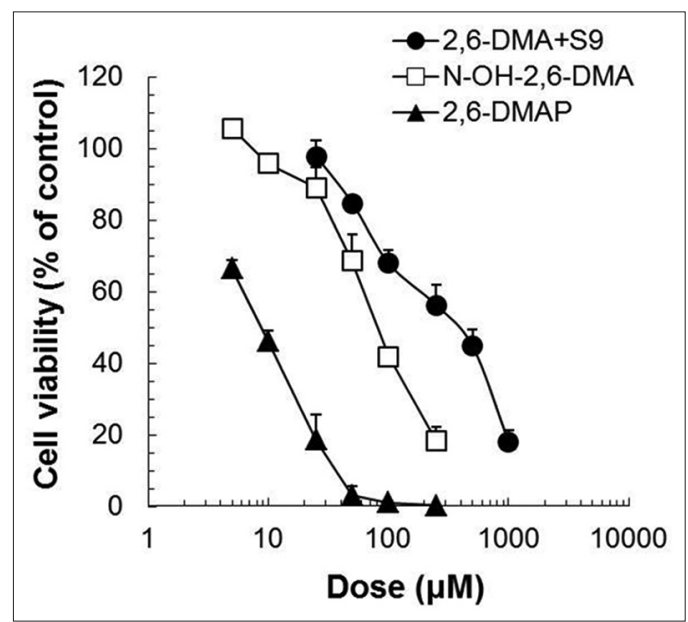

Fig. 2: Dose dependent of cell survival after treatment with

2,6-dimethylaniline, and its $N$-hydroxy and aminophenol metabolites in AS52 cells, Survival was determined by trypan blue assay $24 \mathrm{~h}$ after treatment, data represent mean \pm standard deviation for three measurements isocitric acid were added per $\mathrm{ml}$ of serum-free medium. Cells were exposed to $25,50,100,250,500$, and $1000 \mu \mathrm{M}$ of 2,6-DMA dissolved in DMSO for $5 \mathrm{~h}$ at $37^{\circ} \mathrm{C}$, after which test compounds containing medium were removed and replated with fresh medium supplemented with $10 \%$ FBS. The final concentration of DMSO to which cells $\mu \mathrm{L}$ were exposed was $<0.1 \%$.

\section{Metabolite treatment}

$\mathrm{N}$-hydroxy and aminophenol metabolites of 2,6-DMA were synthesized as described previously [12]. The cells were seeded at $1 \times 10^{6}$ and incubated overnight with the regular medium. Then, medium changed to one without serum and cells were treated in triplicate with 5, 10, 25, 50,100 , and $250 \mu \mathrm{M}$ of $N$-hydroxy or aminophenol metabolites. After $1 \mathrm{~h}$ treatment, the culture was washed with PBS, amended with Ham's F-12 medium containing 10\% FBS, and incubated.

Measurement of survival and $g$ pt mutations

Cytotoxicity was determined by trypan blue exclusion assay $24 \mathrm{~h}$ after treatment, and the cells were maintained for full expression of the mutant phenotype. 7 days after treatment, $5 \times 10^{5}$ cells from each

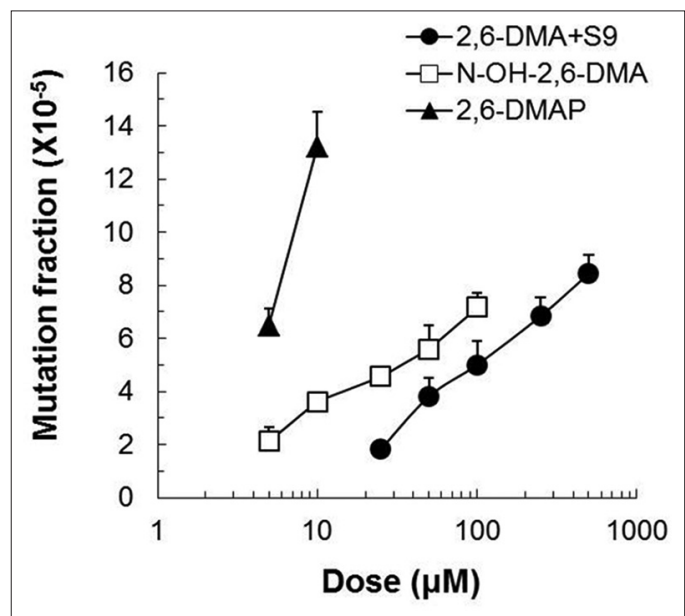

Fig. 3: Induced mutation fraction in AS52 cells treated with 2,6-dimethylaniline, and its $\mathrm{N}$-hydroxy and aminophenol metabolites, data represent mean \pm standard deviation for three measurements

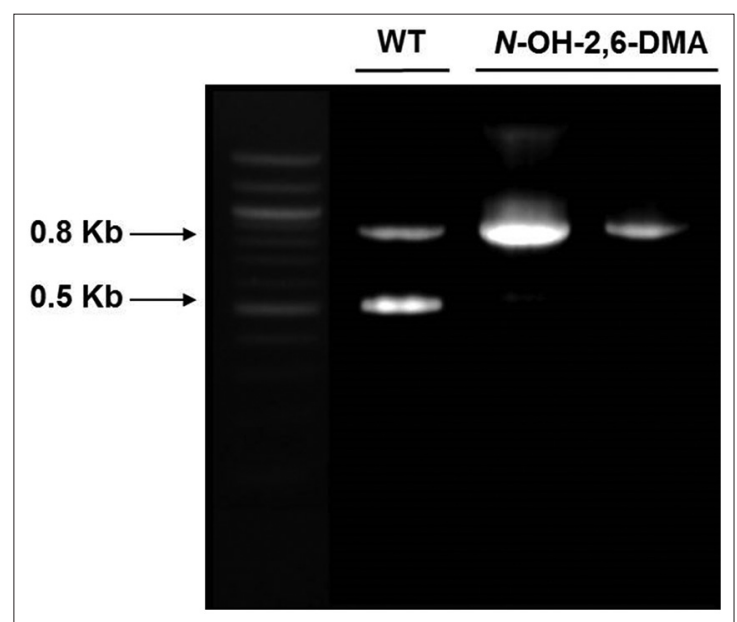

Fig. 4: Nested polymerase chain reaction (PCR) amplication of the gpt gene in AS52 cells. Two prominent bands at 0.5 (gpt structural gene) and $0.8 \mathrm{~kb}$ (rearranged pSV gpt gene) are observed in wild-type AS52 cells (WT), mutants generated by $\mathrm{N}-\mathrm{OH}-2,6-\mathrm{DMA}$, rearranged pSV gpt band are present, but the PCR product for the structural gene is missing; $1 \mathrm{~kb}$ ladders are shown in left lane 
Table 1: PCR analysis of gpt in AS52 Cells after treatment with 2,6-DMA and its metabolites

\begin{tabular}{|c|c|c|c|c|}
\hline & \multicolumn{4}{|c|}{ Number of mutants (\%) } \\
\hline & Spontaneous & 2,6-DMA & $\mathrm{N}-\mathrm{OH}-2,6-\mathrm{DMA}$ & 2,6-DMAP \\
\hline No observable alteration ${ }^{\mathrm{a}}$ & $23(96)$ & $35(100)$ & $33(94)$ & $34(100)$ \\
\hline Large deletions/rearrangements ${ }^{\mathrm{b}}$ & $1(4)$ & $0(0)$ & $2(6)$ & $0(0)$ \\
\hline Total of mutants analyzed & $24(100)$ & $35(100)$ & $35(100)$ & $34(100)$ \\
\hline
\end{tabular}

group was placed in $100 \mathrm{~mL}$ of selection medium containing $10 \mu \mathrm{M}$ 6-TG and plated at 50,000 cells/10 mL/100 mm dish (10 dishes per group) for the determination of mutagenicity. Simultaneously with 6-TG selection, cells were seeded for the determination of plating efficiency (200 cells/10 mL/100 mm dish; 5 dishes per group). Colonies were scored after incubation for 14 days, and mutant fraction was calculated as the number of 6-TG mutants. The MF was calculated by dividing the number of mutants by the number of cells seeded and the plating efficiency. In one of the experiments, exposure to 8 mMEMS for $2 \mathrm{~h}$ was used as a positive control for mutation induction. Identified single $g p t$ mutant colony was then grown to approximately $2 \times 10^{6}$ mutant cells for molecular analysis.

\section{DNA isolation and polymerase chain reaction (PCR) deletion screening}

Identified single gpt mutant colony was transferred to 24-well plates for propagating mutant cells. Approximately $2 \times 10^{6}$ mutant cells were collected for molecular analysis. Genomic DNA was extracted from each mutant using a GenElute ${ }^{\mathrm{TM}}$ mammalian genomic DNA miniprep kit (Sigma). Amplification of the gDNA was performed in two rounds of nested PCR in PTC-200 DNA Engine Thermal Cycler (Bio-Rad, Hercules, CA). About $1 \mu \mathrm{g}$ of template DNA was transferred into the first round mix of $10 \mu \mathrm{L} 10 \times$ PCR buffer, $2 \mu \mathrm{L}$ dNTP mix, $0.5 \mu \mathrm{L}$ taq polymerase, $73.5 \mu \mathrm{L}$ high-performance liquid chromatography water, $0.2 \mu \mathrm{L}$ each $25 \mathrm{mM}$ forward (bases - 199 to - 181; 5'-AAGCTTGGACACAAGACAG-3') and reverse (bases 520 to 540; 5'-CCAGAATACTTACTGGAAAC-3') primer and amplified with a PCR profile of $94^{\circ} \mathrm{C}$ : $1 \mathrm{~min}, 30$ cycles of $94^{\circ} \mathrm{C}$ : $1 \mathrm{~min}, 47^{\circ} \mathrm{C}: 1 \mathrm{~min}, 72^{\circ} \mathrm{C}: 1 \mathrm{~min}$ and a final extension of $72^{\circ} \mathrm{C}$ for $7 \mathrm{~min}$. The product from this reaction was filtered using Centricon 50 concentrator (Amicon, Beverly, MA) and resuspended in $100 \mu \mathrm{L}$ sterile water to avoid unspecific binding with remaining primers, and $10 \mu \mathrm{L}$ aliquot was used as template in the second round of PCR using nested primers (bases -23 to -4; 5'-ATAAACAGGCTGGGACACTT-3' and bases 460 to 470 ; 5'-AGTGCCAGGCGTTGAAAAGA-3'). The PCR conditions were the same in the second round as those in the first round reaction, except annealing temperature $\left(52^{\circ} \mathrm{C}\right)$. A quantity of $g p t$ gene amplification was analyzed by electrophoresis on $1 \%$ agarose gels stained with ethidium bromide.

\section{RESULTS AND DISCUSSION}

\section{Survival and MFs}

Alkylaniline toxicity is characterized by methemoglobin formation and by hyperplasia and siderosis of the spleen [18]. The compound is nonmutagenic in the standard Salmonella typhimurium/microsome test [19]. It is positive, however, in inducing DNA damage in the liver and kidney of rats and in inducing sister chromatid exchanges in vivo in mice [20]. Alkylaniline, at a high concentration, induces minimal increases in sister chromatid exchanges in vitro [21] and forms DNA adducts $[6,11]$. Mutagenic activity of a chemical is a function of both the capacity to adduct DNA and the capacity of the cell to respond to the damage. DNA adducts formed from distinct alkylanilines have already been shown to be differentially mutagenic [22].

In the present study, all test compounds reduced the cell survival, whereas they increased the proportion of cells carrying the mutated gpt gene in a dose-dependent manner (Figs. 2 and 3). The survival of the test cell lines following 2,6-dimethyaminophenol (2,6-DMAP) treatment was lower than that observed in the corresponding $N$-hydroxy metabolite and parent compound; for instance, cell viability was $3 \%$ in AS52 cells $24 \mathrm{~h}$ after a dose of $50 \mu \mathrm{M}$ 2,6-DMAP, compared to $69 \%$ and $85 \%$ after treatment with $N$-hydroxy-2,6-DMA $(N-O H-2,6-$ DMA) and 2,6-DMA, respectively (Fig. 2).

Previous studies showed that, if the relative survival rate is $30 \%$ or more after chemical exposure, there will be sufficient live cells to determine mutation responses $[23,24]$. Thus, based on the results of cytotoxicity experiment, three cultures with those concentration ranges for 2,6-DMA (25-500 $\mu \mathrm{M}), \mathrm{N}-\mathrm{OH}-2,6-\mathrm{DMA}(5-100 \mu \mathrm{M})$, and 2,6-DMAP ( 5 and $10 \mu \mathrm{M}$ ) were used to determine mutagenic responses (Fig. 3). When cells were treated with $100 \mu \mathrm{M}$ of 2,6-DMA and $N$-OH-2,6-DMA, MF was $5.01 \times 10^{-5}$ and $7.17 \times 10^{-5}, 3$ - and 4.5 -fold the spontaneous MF $\left(1.61 \times 10^{-5}\right)$, respectively. On the other hand, $5 \mu \mathrm{M}$ 2,6-DMAP, which is 20 times lower concentration, enhanced the MF from $1.61 \times 10^{-5}$ to $6.48 \times 10^{-5}$ (Fig. 3). By comparison, in EMS-treated positive controls, MF at the $g p t$ locus was $72.7 \times 10^{-5}$.

Our results correlated well with that obtained by previous studies showing both phase I and phase II metabolism are required for genotoxic-specific activation of 2,6-DMA. Nohmi et al. reported the presence of the mutagenic $N$-hydroxylated metabolite of 2,4-DMA in an in vitro rat liver microsomal system (S9) in which the yield of the mutagenic metabolite increased with increasing S9 content [25]. Beland et al. reported the mutagenicity of the $N$-hydroxylated metabolite of 2,6-DMA toward S. typhimurium (TA100) [26].

\section{Deletion screening of AS52gpt mutants}

Thirty-five independent $500 \mu \mathrm{M}$ 2,6-DMA and $100 \mu \mathrm{M} N$-OH-2,6-DMA, 34 independent $10 \mu \mathrm{M}$ 2,6-DMAP, and 24 independent spontaneous 6-TG-resistant mutants in AS52 cells were isolated and analyzed by the nested PCR, to test for the presence or absence of the gpt structural gene ( $0.5 \mathrm{~kb}$ PCR product) and the closely linked rearrangement product of this gene ( $0.8 \mathrm{~kb}$ PCR product). Those 6-TG-resistant mutants with both PCR sequences intact are mostly likely to carry point mutations in the gpt structural gene. Loss or alteration of one or both bands suggests more complex chromosomal deletions [27] and/or rearrangements involving gpt $[28,29]$.

Screening results of the gpt gene deletions showed that the percentage of deletion mutations in the spontaneous gpt mutants was 4\% (1 of 24): That of the $100 \mu \mathrm{MN}-\mathrm{OH}-2,6-\mathrm{DMA}$-enhanced mutants was $6 \%$ (2 out of 35) (Table 1 and Fig. 4). The mechanisms for the gene deletion are complicated and may involve different pathways such as DNA strand breakage, error in DNA damage repair, and other kinds of DNA damages [30]. Deletion of the gpt genein $\mathrm{N}-\mathrm{OH}-2,6-\mathrm{DMA}$-enhanced mutants may be result from DNA damage caused by high cytotoxicity of the chemical.

\section{CONCLUSION}

The results reveal that 2,6-DMA is mutagenic and genotoxic in gpt gene of AS52 cells when activated by Phases I and II metabolism, in which the aminophenol metabolites were considerably more potent than the corresponding $N$-hydroxylamines. Further study is also needed to investigate the mechanism of genotoxic activity of 2,6-DMA. 


\section{ACKNOWLEDGMENT}

This work was supported by Basic Science Research Program (2017R1D1A1B03028849, 2016R1A6A1A03012862, and 2014R1A1A2056292) through the National Research Foundation of Korea funded by the Ministry of Education, Science, and Technology, Republic of Korea.

\section{AUTHORS' CONTRIBUTION}

All authors had equally contributed the research work.

\section{CONFLICTS OF INTEREST}

We declare that there is no conflict of interest.

\section{REFERENCES}

1. 2,6-dimethylaniline (2,6-xylidine). IARC Monogr Eval Carcinog Risks Hum 1993;57:323-35.

2. Matilde Marques M, Gamboa da Costa G, Blankenship LR, Culp SJ, Beland FA. The effect of deuterium and fluorine substitution upon the mutagenicity of N-hydroxy-2,6-dimethylaniline. Mutat Res 2002;506-507:41-8.

3. Luceri F, Pieraccini G, Moneti G, Dolara P. Primary aromatic amines from side-stream cigarette smoke are common contaminants of indoor air. Toxicol Ind Health 1993;9:405-13.

4. Palmiotto G, Pieraccini G, Moneti G, Dolara P. Determination of the levels of aromatic amines in indoor and outdoor air in Italy. Chemosphere 2001;43:355-61.

5. Cohen SM, Johansson SL. Epidemiology and etiology of bladder cancer. Urol Clin North Am 1992;19:421-8.

6. Gan J, Skipper PL, Gago-Dominguez M, Arakawa K, Ross RK, Yu MC, et al. Alkylaniline-hemoglobin adducts and risk of non-smoking-related bladder cancer. J Natl Cancer Inst 2004;96:1425-31.

7. Skipper PL, Tannenbaum SR, Ross RK, Yu MC. Nonsmoking-related arylamine exposure and bladder cancer risk. Cancer Epidemiol Biomarkers Prev 2003;12:503-7.

8. IARC Working Group on the Evaluation of Carcinogenic Risks to Humans. Chemical agents and related occupations. IARC Monogr Eval Carcinog Risks Hum 2012;100:9-562.

9. Tao L, Day BW, Hu B, Xiang YB, Wang R, Stern MC, et al. Elevated 4-aminobiphenyl and 2,6-dimethylaniline hemoglobin adducts and increased risk of bladder cancer among lifelong nonsmokers-the shanghai bladder cancer study. Cancer Epidemiol Biomarkers Prev 2013;22:937-45.

10. Skipper PL, Kim MY, Sun HL, Wogan GN, Tannenbaum SR. Monocyclic aromatic amines as potential human carcinogens: Old is new again. Carcinogenesis 2010;31:50-8.

11. Skipper PL, Trudel LJ, Kensler TW, Groopman JD, Egner PA, Liberman RG, et al. DNA adduct formation by 2,6-dimethyl-, 3,5-dimethyl-, and 3-ethylaniline in vivo in mice. Chem Res Toxicol 2006;19:1086-90.

12. Chao MW, Kim MY, Ye W, Ge J, Trudel LJ, Belanger CL, et al. Genotoxicity of 2,6- and 3,5-dimethylaniline in cultured mammalian cells: The role of reactive oxygen species. Toxicol Sci 2012;130:48-59.

13. Damani LA. Oxidation at Nitrogen Centers. Metabolic Basis of Detoxication. New York, NY: Academic Press; 1982.

14. Nelson SD. Arylamines and arylamides: Oxidation mechanism. In: Anders MW, editor. Bioactivation of Foreign Compounds. Orlando, FL: Academic Press, Inc.; 1985.

15. Gan J, Skipper PL, Tannenbaum SR. Oxidation of 2,6-dimethylaniline by recombinant human cytochrome $\mathrm{P} 450 \mathrm{~s}$ and human liver microsomes. Chem Res Toxicol 2001;14:672-7.

16. Tindall KR, Stankowski LF Jr. Machanoff R, Hsie AW. Detection of deletion mutations in pSV2gpt-transformed cells. Mol Cell Biol 1984:4:1411-5.

17. Tindall KR, Stankowski LF Jr. Machanoff R, Hsie AW. Analyses of mutation in pSV2gpt-transformed $\mathrm{CHO}$ cells. Mutat Res 1986;160:121-31.

18. Sun JD, Bus JS. Comparison of covalent binding of $14 \mathrm{C}$-aniline $\mathrm{HCl}$ in red blood cells, spleen and liver of rats. Pharmacologist 1980;22:247.

19. Simmon VF. In vitro mutagenicity assays of chemical carcinogens and related compounds with salmonella typhimurium. J Natl Cancer Inst 1979;62:893-9.

20. Parodi S, Pala M, Russo P, Zunino A, Balbi C, Albini A, et al. DNA damage in liver, kidney, bone marrow, and spleen of rats and mice treated with commercial and purified aniline as determined by alkaline elution assay and sister chromatid exchange induction. Cancer Res 1982;42:2277-83.

21. Wilmer JL, Kligerman AD, Erexson GL. Sister chromatid exchange induction and cell cycle inhibition by aniline and its metabolites in human fibroblasts. Env Mutagen 1981;3:627-38.

22. Marques MM, Mourato LL, Amorim MT, Santos MA, Melchior WB Jr. Beland FA, et al. Effect of substitution site upon the oxidation potentials of alkylanilines, the mutagenicities of N-hydroxyalkylanilines, and the conformations of alkylaniline-DNA adducts. Chem Res Toxicol 1997; 10:1266-74.

23. Li CQ, Trudel LJ, Wogan GN. Nitric oxide-induced genotoxicity, mitochondrial damage, and apoptosis in human lymphoblastoid cells expressing wild-type and mutant p53. Proc Natl Acad Sci U S A 2002;99:10364-9.

24. Li CQ, Trudel LJ, Wogan GN. Genotoxicity, mitochondrial damage, and apoptosis in human lymphoblastoid cells exposed to peroxynitrite generated from SIN-1. Chem Res Toxicol 2002;15:527-35.

25. Nohmi T, Miyata R, Yoshikawa K, Nakadate M, Ishidate M Jr. Metabolic activation of 2,4-xylidine and its mutagenic metabolite. Biochem Pharmacol 1983;32:735-8.

26. Beland FA, Melchior WB Jr. Mourato LL, Santos MA, Marques MM. Arylamine-DNA adduct conformation in relation to mutagenesis. Mutat Res 1997;376:13-9.

27. Gupta M, Dahiya J, Marwaha RK, Dureja H. Therapies in cancer treatment: An overview. Int J Pharm Pharm Sci 2015;7:1-9.

28. Dave M, Daga A, Rawal R. Structural and functional analysis of AF-9 MLL oncogene fusion protein using homology modeling and stimulation based approach. Int J Pharm Pharm Sci 2015;7:155-61.

29. Ferguson LR, Turner PM, Hart DW, Tindall KR. Amsacrine-induced mutations in AS52 cells. Environ Mol Mutagen 1998;32:47-55.

30. Hutchinson F. Chemical changes induced in DNA by ionizing radiation. Prog Nucleic Acid Res Mol Biol 1985;32:115-54. 